\title{
Nurses' knowledge level on lymphedema, attitudes and behaviors towards teaching lymphedema prevention and factors affecting these behaviors
}

\section{Hemşirelerin lenfödem bilgi düzeyleri, lenfödemi önlemeyi öğretmeye yönelik tutum ve davranışları ve bu davranışları etkileyen faktörler}

\author{
Sultan ÖZKAN1@(D) \\ ${ }^{1}$ Aydin Adnan Menderes University, Faculty of Nursing, Department of Surgical Diseases Nursing, 09010, Aydın- \\ Turkey
}

Atıf gösterme/Cite this article as: Özkan S. Nurses' knowledge level on lymphedema, attitudes and behaviors towards teaching lymphedema prevention and factors affecting these behaviors. ADYÜ Sağlık Bilimleri Derg. 2021;7(3):200212. doi:10.30569.adiyamansaglik. 901423

\begin{abstract}
Aim: To determine the knowledge levels of nurses about lymphedema, their attitudes towards lymphedema prevention teaching, their behaviors of teaching lymphedema prevention after cancer surgery and to examine the influencing factors.

Materials and Methods: The study was conducted with 507 nurses in three hospitals. The data were obtained with a data collection form examining the nurses' descriptive characteristics, lymphedema knowledge, and attitudes and behaviors towards lymphedema prevention teaching. Descriptive analysis such as frequency and percentage and multiple linear regression analysis were used in data analysis.

Results: Nurses' knowledge level of lymphedema was found to be below the average, their attitudes towards lymphedema prevention education were found to be high, but it was observed that they did not do their teaching behaviors adequately. Factors affecting behavior; level of knowledge, attitude, presence of lymphedema patient in the unit, department of work, year of study and gender.

Conclusion: The findings of the study revealed that nurses need a standardized lymphedema prevention training in order to prevent the development of lymphedema in patients undergoing cancer surgery.

Keywords: Behavior; Education; Patient; Nurse; Lymphedema; Attitude.
\end{abstract}

\begin{abstract}
$\ddot{\mathbf{O z}}$
Amaç: Hemşirelerin lenfödem hakkındaki bilgi düzeylerini, lenfödem önleme öğretimine yönelik tutumlarını, kanser cerrahisi sonrası lenfödemden korunmayı öğretme davranışlarını belirlemek ve etkileyen faktörleri incelemektir.

Gereç ve Yöntem: Araştırma, üç hastanede 507 hemşire ile yapıldı. Veriler hemşirelerin tanıtıcı özelliklerini, lenfödem bilgisini ve lenfödem önleme ögretimine yönelik tutum ve davranışlarını irdeleyen veri toplama formu ile elde edildi. Veri analizinde, frekans ve yüzde gibi tanımlayıcı analizler ve çoklu linear regresyon analizi kullanıldı.

Bulgular: Hemşirelerin lenfödem bilgi düzeyleri ortalamanın altında, lenfödemi önleme eğitimine yönelik tutumları yüksek bulundu fakat lenfödemden korunmayı öğretme davranışlarını yeterince yapmadığı görüldü. Davranışı etkileyen faktörler; bilgi düzeyi, tutum, çalışılan birimde lenfödem hastasının varlığ çalıştı̆̆ bölüm, çalışma yılı ve cinsiyet.

Sonuç: Araştırmadan elde edilen bulgular, kanser cerrahisi uygulanan hastalarda lenfödem gelişimini önlemek amacıyla, hemşirelerin standartlaştırılmış bir lenfödemi önleme eğitimine gereksinimi olduğunu ortaya koydu.
\end{abstract}

Anahtar Kelimeler: Davranış; Eğitim; Hasta; Hemşire; Lenfödem; Tutum.

Yazışma Adresi/Address for Correspondence: Sultan ÖZKAN, Aydin Adnan Menderes University, Faculty of Nursing, Department of Surgical Diseases Nursing, 09010, Aydın-Turkey, E-mail: sultanozkan2000@yahoo.com

Geliş Tarihi/Received:22.03.2021 Kabul Tarihi/Accepted:17.08.2021 Yayım Tarihi/Published online:31.12.2021 


\section{Introduction}

Despite the increase in the number of individuals diagnosed with cancer in recent years, advances in early diagnosis, surgery and medical treatments have increased the survival rate. By cause of cancer or cancerrelated treatments, negative physical and psychological effects experienced by most cancer patients occur. ${ }^{1}$ Secondary lymphedema (LE) may develop after cancer surgery (head-neck, breast, abdominal, urological and gynecological cancers, etc.). ${ }^{2-5}$ Considered as one of the most troublesome side effects of cancer treatment, LE is the accumulation of protein-rich lymph fluid in the subcutaneous tissue with a decrease in the carrying capacity of the lymphatic system. ${ }^{3}$ Although it is most common in the lower extremities, it can also be seen on the arm, face, neck and external genital area. It is unilateral in two-thirds of patients. ${ }^{2}$ Several signs of discomfort or feeling are accompanied by LE, including swelling, pain, numbness, tightness, heaviness, and reduced physical movement. ${ }^{6}$ It causes physical and psychosocial problems in individuals, which is complicated by chronic, progressive and recurrent infections, which often requires hospital admission and can be fatal if untreated or inadequately treated. ${ }^{7-10}$ Cancer patients are at risk for the development of LE, particularly following lymphadenectomy, adjuvant radiotherapy, or associated with important clinical risk factors. ${ }^{10}$ Although it is seen in both sexes, it is more common in women. ${ }^{2}$ Age, high body mass index (BMI), hysterectomy, radiotherapy, number of concurrent diseases, surgeon performance, disease stages, degree of disease, number of lymph nodes removed, type of surgery (pelvic and/or para-aortic resection), cancer type and number pose risks for LE in patient. ${ }^{2,5,7,8,11,12}$ As there is no cure for LE, precautions and prevention is important for its severe longterm effects and mortality. ${ }^{8,13,14}$ It could be prevented or reduced by appropriate nursing interventions. ${ }^{7}$ In the prevention of LE, nurses play a vital role in helping people take responsibility for their own LE., ${ }^{7,15,16}$ Studies show that most cancer patients are not informed about LE. ${ }^{5,14,17,18}$ This may be due to the nurses' inadequate knowledge level or not seeing patient education as their role. ${ }^{15,19}$ When education is ignored, it becomes inadequate for patients to cope with this risk. Teaching patients how to prevent LE will also increase their self-esteem and quality of life. ${ }^{15,18}$ To effectively educate patients on LE, it is necessary to develop an understanding that nurses have sufficient clinical knowledge and that patient education is required after cancer surgery. ${ }^{17}$ Although there is a big trend today regarding the necessity of LE patient education, there are not enough studies investigating nurse attitudes. There are no studies examining nurses' knowledge, attitudes and behaviors to prevent LE. Nurses should teach patients about LE prevention and care methods in preventing LE, which is an important problem encountered after cancer surgery. If nurses do not have sufficient knowledge about lymphedema, they will not think that prevention is necessary and will not teach patients to avoid it. This study aimed to determine the knowledge levels of nurses about LE, their attitude levels towards LE prevention teaching, their behaviors of teaching LE prevention and the factors that affect the teaching of prevention.

\section{Research questions}

The research questions were as follows:

1: Are the nurses' levels of knowledge about LE sufficient?

2: What are the nurses' attitude levels towards patient teaching to prevent LE?

3: Do the nurses teach patients towards LE prevention?

4: What are the factors affecting nurses' teaching behaviors towards LE prevention?

\section{Materials and Methods}

\section{Study type}

This research was designed as descriptive study.

\section{Study population}

The research population consisted of 1208 nurses working in one University and two State hospitals in a city in the west of Turkey. 
Regardless of the unit they work in, 523 nurses filled the forms on a voluntary basis, but 16 forms were canceled due to incomplete or incorrect filling. The sample of the study consisted of 507 nurses.

\section{Data collection tools}

Data were collected with questionnaires prepared on the basis of literature information. ${ }^{1,5,6,9}$

The following instruments were used:

1. In the section consisting of 'Nurses' Descriptive Characteristics (DC)", there are a total of 16 questions including the personal characteristics (9 items) of nurses and their LE related descriptive characteristic (7 items).

2. "Nurses' LE Knowledge (LEK) Form" includes 25 questions in total in 6 themes containing information about lymphedema. In order to calculate LEK scores, each correct answer of the nurses was evaluated as 1 point and incorrect answers were evaluated as 0 points for the information questions in the form. While the nurses got the highest score of 25 on this form, they got the lowest score of 0 . The level of knowledge was calculated by converting the scores $(25 \times 4=100$ points $)$ into a 100-point system. The high LEK scores indicates that nurses' level of knowledge on this issue is good.

3. "Nurses' Teaching Attitudes towards LE Prevention (TALEP) Form" was used to detect nurses' teaching attitude levels towards LE prevention. Twenty items on the attitude dimension were evaluated on a 7-point Likert scale ranging from 1 to 7 (1=disagree strongly, $2=$ disagree, $3=$ partly disagree, $4=$ no idea, 5=partly agree, 6=agree and 7=agree strongly). Nurses' TALEP form minimum and maximum points were 20 and 140, respectively. Higher scores indicated more positive nurses' teaching attitudes towards LE prevention.

4. 'Nurses' Teaching Behaviors towards LE Prevention (TBLEP) Form" was evaluated by giving "I do not=1 point" and "I $d o=2$ points" to 20 questions in the attitude form. Nurses scored the lowest 20 and the highest 40 in the behavioral form. A score above the arithmetic mean showed that the behavior was done. Those below 30 points were categorized as not doing the behavior, those above 31 points were accepted as doing. The high score obtained indicates that the nurses teach (have taught) the information that should be taught to patients about the prevention of LE.

\section{Data collection}

For the content validity of the questionnaire, the opinions of 10 experts, consisting of experienced faculty members, physicians and nurses, were obtained by using the Lawshe method (Content Validity IndexCVI=0.79). The questions were reviewed again and the pre-application was made to 10 nurses after the necessary arrangements, and these persons were not included in the sample. ${ }^{20,21}$

The data were collected between $1^{\text {st }}$ June and $1^{\text {st }}$ July 2018. The nurses were asked to fill out the questionnaires using the self-report method during rest breaks. The questionnaires took an average of 20-25 minutes to answer. Completed forms were collected by the researcher. Each unit was visited at least three times, in two shifts, and those who gave up filling the questionnaire or filled incompletely were excluded from the study.

The Cronbach's alpha reliability coefficient of LEK questions is $\alpha=0.82$. Nurses' LEK scores are $(\min -\max =12-88) \quad \mathrm{M}=42.74$, $(\mathrm{IQR}=28.00-56.00)$. TALEP scores are (min$\max =20-140) \quad \mathrm{M}=119.98, \quad(\mathrm{IQR}=106.00$ 133.00), cronbach $\alpha=0.99$ and TBLEP scores are (min-max $=20-40) \mathrm{M}=20.00$, (IQR=20.0035.00). The TBLEP cronbach alpha reliability coefficient is $\alpha=0.98$

\section{Ethical consideration}

In order to conduct the study, the approval of the Aydin Adnan Menderes University Faculty of Nursing Non-Invasive Clinical Research Ethics Committee (50107718050.04.04) and written permission were obtained from the specified hospitals. Before obtaining consent from the nurses participating in the study, the purpose of the study was explained. It was also assumed that the nurses answered all survey questions truthfully, because confidentiality were preserved throughout the study. All nurses 
participated voluntarily and had the right to withdraw from the study at any time. The study was conducted in accordance with the declaration of Helsinki

\section{Statistical analysis}

Data were analyzed using the IBM-SPSS for Windows version 22.0 software package. To determine the normality of data distribution, the Shapiro-Wilk test was used. For descriptive statistics, frequency, percentage, mean, median, and standard deviation were used. We used the Chi-square test for categorical variables for two-group comparisons, the Mann-Whitney U test and, in other cases, the Kruskal Wallis-H test. To classify independent predictors of preventing LE teaching activity and to evaluate confounding effects between potentially independent predictors, a multiple linear regression (MLR) model was used. To build MLR models, a stepwise method was used. Depending on the importance (probability) of the $F$ value, variables could be entered or excluded from the model. If the likelihood of its score statistics was less than the input value (0.05), a variable was entered into the model and it was excluded if the likelihood was greater than the removal value $(0.1)$. Model fit was assessed using appropriate and goodness-of-fit statistics. Multicollinearity was tested using a variance inflation factor (VIF), and autocorrelation was tested using Durbin-Watson statistics. Results with a $p$ value of $<0.05$ were considered statistically significant.

\section{Results}

$50.5 \%$ of the nurses in the study work in a university hospital, the average age was $(34.54 \pm 8.61)$ and $34.9 \%$ of them are in the 19-29 age range. $27.0 \%$ of the nurses have 15 years of working experience, $60.2 \%$ are working in the surgical unit, $52.9 \%$ are working in the clinic and $93.1 \%$ are working as staf. (Table 1).

$\underline{\text { Table 1. Nurses' descriptive characteristics }(n=507)}$

\begin{tabular}{|c|c|c|c|}
\hline & & \multicolumn{2}{|c|}{ Sample rates } \\
\hline & & $\mathrm{n}$ & $\%$ \\
\hline \multirow{3}{*}{ Type of Hospital } & University Hospital & 256 & 50.5 \\
\hline & State 1 Hospital & 150 & 29.6 \\
\hline & State 2 Hospital & 101 & 19.9 \\
\hline \multirow{4}{*}{$\begin{array}{l}\text { Age } \\
34.54 \pm 8.61 \\
(19-56)\end{array}$} & $19-29$ & 177 & 34.9 \\
\hline & $30-39$ & 166 & 32.7 \\
\hline & $40-49$ & 147 & 29.0 \\
\hline & $50+$ & 17 & 3.4 \\
\hline \multirow{2}{*}{ Gender } & Female & 451 & 89.0 \\
\hline & Male & 56 & 11.0 \\
\hline \multirow{2}{*}{ Marital status } & Single & 363 & 71.6 \\
\hline & Married & 144 & 28.4 \\
\hline \multirow{4}{*}{ Education level } & High School & 62 & 12.2 \\
\hline & Vocational school & 100 & 19.7 \\
\hline & Bachelor degree & 305 & 60.2 \\
\hline & Postgraduate & 40 & 7.9 \\
\hline \multirow{3}{*}{ Working year } & $1-5$ & 137 & 27.0 \\
\hline & $6-10$ & 95 & 18.7 \\
\hline & $11-15$ & 68 & 13.4 \\
\hline \multirow[t]{2}{*}{$13.16 \pm 8.87(1-39)$} & $16-20$ & 90 & 17.8 \\
\hline & $20+$ & 117 & 23.1 \\
\hline \multirow{2}{*}{ Department of working } & Surgical & 305 & 60.2 \\
\hline & Medical & 202 & 39.8 \\
\hline \multirow{3}{*}{ Working unit } & Clinic & 268 & 52.9 \\
\hline & ICU & 132 & 26.0 \\
\hline & Other & 107 & 21.1 \\
\hline \multirow{2}{*}{ Working position } & Staff nurse & 472 & 93.1 \\
\hline & Manager nurse & 35 & 6.9 \\
\hline
\end{tabular}


The nurses' knowledge was calculated over 100 points and their knowledge level was found to be $43.18 \pm 18.38$ below the average. When the knowledge scores were categorized, the scores obtained by the nurses were as follows: 331 nurses $(65.3 \%)$ between 0-49, 141 nurses (27.8\%) 50-75, 35 nurses 76 and above (6.9\%). In the LE information questions regarding the risk factors affecting the development of LE; surgical method (71.2\%), age (75.1\%), chemotherapy (74.0\%),

Table 2. Nurses' knowing status of questions about LE ( $\mathrm{n}=507$ )

\begin{tabular}{|c|c|c|c|c|}
\hline \multirow{2}{*}{$\begin{array}{l}\text { Questio } \\
\text { What are the risk factors affecting the development of LE } \\
\text { present in the patient after cancer surgery? }\end{array}$} & & Knowing Status & $\mathrm{n}$ & $\%$ \\
\hline & Surgical method & Unknown & 361 & 71.2 \\
\hline & \multirow[t]{2}{*}{ Disease-related factors Tumor stage } & Known & 246 & 48.5 \\
\hline & & Unknown & 261 & 51.5 \\
\hline & Lymph node involvement & Unknown & 252 & 49.7 \\
\hline & \multirow[t]{2}{*}{ Number of excised lymph nodes } & Known & 188 & 37.1 \\
\hline & & Unknown & 319 & 62.9 \\
\hline & Tumor stage & Known & 192 & 37.9 \\
\hline & Age & Unknown & 381 & 75.1 \\
\hline & \multirow[t]{2}{*}{ Chemotherapy } & Known & 132 & 26.0 \\
\hline & & Unknown & 375 & 74.0 \\
\hline & \multirow[t]{2}{*}{ Radiotherapy } & Known & 134 & 26.4 \\
\hline & & Unknown & 373 & 73.6 \\
\hline & \multirow[t]{2}{*}{ Presence of diabetes } & Known & 150 & 29.6 \\
\hline & & Unknown & 357 & 70.4 \\
\hline & Smoking & Unknown & 364 & 71.8 \\
\hline & \multirow[t]{2}{*}{ Type of lymph node surgery } & Known & 137 & 27.0 \\
\hline & & Unknown & 370 & 73.0 \\
\hline \multirow{2}{*}{\multicolumn{2}{|c|}{ Clinical Stages of LE }} & Known & 282 & 55.6 \\
\hline & & Unknown & 225 & 44.4 \\
\hline \multicolumn{2}{|l|}{ Can patients control LE themselves? } & Known & 296 & 58.4 \\
\hline
\end{tabular}

radiotherapy $(73.6 \%)$, presence of diabetes $(70.4 \%)$, body mass index (75.5), smoking (71.8), and type of lymph node surgery (73.0\%) were mostly unknown by the nurses. In addition, swelling (83.2\%) and trophic changes $(85.4 \%)$ were the most known signs and symptoms of LE. When to start extremity circumference measurements? (70.5\%) and how often should the patient check himself/herself in order to recognize LE $(80.2 \%)$ questions were mostly answered incorrectly (Table 2). 


\begin{tabular}{|c|c|c|c|c|}
\hline & & Unknown & 211 & 41.6 \\
\hline \multirow[t]{16}{*}{ Signs and Symptoms of LE } & \multirow[t]{2}{*}{ Swelling } & Known & 422 & 83.2 \\
\hline & & Unknown & 85 & 16.8 \\
\hline & \multirow[t]{2}{*}{ Ache } & Known & 321 & 63.3 \\
\hline & & Unknown & 186 & 36.7 \\
\hline & \multirow[t]{2}{*}{ Heaviness } & Known & 285 & 56.2 \\
\hline & & Unknown & 222 & 43.8 \\
\hline & \multirow[t]{2}{*}{ Tingling } & Known & 196 & 38.7 \\
\hline & & Unknown & 311 & 61.3 \\
\hline & \multirow[t]{2}{*}{ Rash } & Known & 247 & 48.7 \\
\hline & & Unknown & 260 & 51.3 \\
\hline & \multirow[t]{2}{*}{ Trophic changes } & Known & 433 & 85.4 \\
\hline & & Unknown & 74 & 14.6 \\
\hline & \multirow[t]{2}{*}{ Skin temperature } & Known & 264 & 52.1 \\
\hline & & Unknown & 243 & 47.9 \\
\hline & \multirow[t]{2}{*}{ Restricted movement } & Known & 165 & 32.5 \\
\hline & & Unknown & 342 & 67.5 \\
\hline \multirow{2}{*}{\multicolumn{2}{|c|}{ When to start Extremity Circumference Measurements }} & Known & 135 & 26.6 \\
\hline & & Unknown & 372 & 73.4 \\
\hline \multirow{2}{*}{\multicolumn{2}{|c|}{ How often should the patient check herself/himself in order to recognize LE? }} & Known & 75 & 14.8 \\
\hline & & Unknown & 432 & 85.2 \\
\hline
\end{tabular}

When the descriptive characteristics and LEK scores of the nurses are compared, the scores of employees in state 1 hospital $(p=0.001)$, who are 30-39 and 40-49 years old (0.037), females $(p=0.008)$, postgraduates $(p=0.001)$, employees with 16-20 years working experience $(p=0.022)$, and employees working in the clinic $(p=0.013)$, were found significantly higher (Table 3 ).

Nurses' attitude levels towards LE prevention teaching were (min$\max =20-140) 111.65 \pm 30.40$. When the descriptive characteristics of the nurses and the TALEP scores are compared, the TALEP scores of those working in the state 2 hospital $(p=0.039)$, those who are married $(p=0.047)$, those who have vocational education $(p=0.002)$ are significantly lower than the others (Table 3).

Considering the TBLEP status of the nurses, the rate of the nurses who do not do LE prevention teaching behaviors is $75.3 \%$. Compared the descriptive characteristics and TBLEP scores; those working in university hospitals $(p=0.002)$, nurses aged 19-29 ( $p=0.001)$, who were men $(p=0.026)$, working for $1-5$ years $(p=0.001)$, and those working in ICU and clinics $(p=0.001)$ have significantly higher teaching behavior scores (Table 3 ). These results show that TBLEP is performed more by these nurses.

When nurses' LE related descriptive characteristic and TBLEP situations is examined; $84.4 \%$ of the nurses stated that they knew what LE was and $57.8 \%$ of them knew how it developed. During their working life, the nurses stated that they did not receive education about LE $(70.8 \%)$, that they thought that they had insufficient knowledge about LE (83.4\%). It was found that, there were LE patients in the unit where they worked $(41.8 \%)$, patients who had cancer surgery were not informed about LE $(84.0 \%)$ and they stated that training material was not provided (98.4\%). Although they express that they know what LE is 
and how it develops, the number of nurses who do not perform TBLEP was significantly higher (respectively $p=0.028, p \leq 0.001$ ). Significant majority $(p=0.011)$ of the nurses who stated that they did not receive education about LE during their working life $(p=0.005)$ and who did not think that they had sufficient knowledge about LE did not teach LE prevention. Nurses with LE patients in their units $(p \leq 0.001)$ also do not teach in a meaningful way. It was observed that the significant majority $(p \leq 0.001)$ of those who said that patients with cancer surgery were not informed about LE did not perform TBLEP (Table 4).

Table 3. Comparison of LEK scores, TALEP scores and TBLEP scores of according to the descriptive characteristics of the nurses.

\begin{tabular}{|c|c|c|c|c|c|c|c|c|c|c|c|}
\hline & & \multicolumn{5}{|c|}{ LEK Scores } & \multicolumn{2}{|c|}{ TALEP Scores } & \multicolumn{3}{|c|}{ TBLEP Scores } \\
\hline & & $\mathrm{n}(\%)$ & Median & IQR & $\begin{array}{c}\text { statistical test } \\
(p \text { value })\end{array}$ & Median & IQR & $\begin{array}{c}\text { statistical test } \\
(p \text { value })\end{array}$ & Median & IQR & $\begin{array}{c}\text { statistical tes } \\
(p \text { value })\end{array}$ \\
\hline \multirow{3}{*}{$\begin{array}{l}\text { Type of } \\
\text { Hospital }\end{array}$} & Univ. $\mathrm{H}^{\mathrm{a}}$ & $256(50.5)$ & 40.00 & 27.00 & \multirow{3}{*}{$\begin{array}{c}21.74 * \\
(\mathbf{0 . 0 0 1 )} \\
\mathrm{a}<\mathrm{b}, \mathrm{c}<\mathrm{b}\end{array}$} & 120.00 & 27.00 & \multirow{3}{*}{$\begin{array}{c}6.46 * \\
(\mathbf{0 . 0 3 9}) \\
a<c\end{array}$} & 36.00 & 16.00 & $12.91 *$ \\
\hline & $\mathrm{S} 1 \mathrm{H}^{\mathrm{b}}$ & $150(29.6)$ & 48.00 & 29.00 & & 120.00 & 33.50 & & 40.00 & 13.00 & $(0.002)$ \\
\hline & $\mathrm{S} 2 \mathrm{H}^{\mathrm{c}}$ & 101(19.9) & 40.00 & 28.00 & & 120.00 & 18.00 & & 40.00 & 15.00 & $a>b, a>c$ \\
\hline \multirow{4}{*}{$\begin{array}{l}\text { Age } \\
34.54 \pm 8.61 \\
(19-56)\end{array}$} & $19-29^{a}$ & 177(34.9) & 40.00 & 24.00 & \multirow{4}{*}{$\begin{array}{c}8.50 \\
(\mathbf{0 . 0 3 7 )} \\
a<b, a<c\end{array}$} & 120.00 & 30.00 & \multirow{4}{*}{$\begin{array}{c}4.22 \\
(0.239)\end{array}$} & 33.00 & 18.00 & 25.21 \\
\hline & $30-39^{b}$ & $166(32.7)$ & 44.00 & 29.00 & & 120.00 & 25.25 & & 40.00 & 10.25 & (0.001) \\
\hline & $40-49^{c}$ & $147(29.0)$ & 44.00 & 24.00 & & 120.00 & 28.00 & & 40.00 & 13.00 & $a>b, a>c$ \\
\hline & $50+{ }^{\mathrm{d}}$ & $17(3.4)$ & 36.00 & 30.00 & & 120.00 & 24.00 & & 40.00 & 20.00 & \\
\hline \multirow[t]{2}{*}{ Gender } & Female & $451(89.0)$ & 44.00 & 28.00 & \multirow{2}{*}{$\begin{array}{c}U=9899.00^{* *} \\
\boldsymbol{p}=\mathbf{0 . 0 0 8}\end{array}$} & 120.00 & 26.00 & \multirow{2}{*}{$\begin{array}{c}U=12229.50 * * \\
p=0.698\end{array}$} & 40.00 & 15.00 & \multirow{2}{*}{$\begin{array}{c}U=14755.50 * * \\
\boldsymbol{p}=\mathbf{0 . 0 2 6}\end{array}$} \\
\hline & Male & $56(11.0)$ & 32.00 & 34.00 & & 120.00 & 37.25 & & 33.00 & 18.00 & \\
\hline \multirow[t]{2}{*}{ Marital status } & Single & $363(71.6)$ & 44.00 & 28.00 & \multirow{2}{*}{$\begin{array}{c}U=23399.00 * * \\
p=0.065\end{array}$} & 120.00 & 27.00 & \multirow{2}{*}{$\begin{array}{c}U=23192.00 * * \\
\boldsymbol{p}=\mathbf{0 . 0 4 7}\end{array}$} & 40.00 & 15.00 & \multirow{2}{*}{$\begin{array}{c}U=28804.00 * * \\
p=0.052\end{array}$} \\
\hline & Married & $144(28.4)$ & 40.00 & 28.00 & & 120.00 & 34.25 & & 36.50 & 15.75 & \\
\hline \multirow{4}{*}{$\begin{array}{l}\text { Education } \\
\text { level }\end{array}$} & High Sch $^{\mathrm{a}}$ & $62(12.2)$ & 38.00 & 36.00 & \multirow{4}{*}{$\begin{array}{r}17.08 * \\
(\mathbf{0 . 0 0 1 )} \\
a<d, b<d\end{array}$} & 120.00 & 31.50 & \multirow{4}{*}{$\begin{array}{l}14.81^{*} \\
(\mathbf{0 . 0 0 2}) \\
\mathrm{b}<\mathrm{c}, \mathrm{b}<\mathrm{d}\end{array}$} & 35.00 & 19.00 & \multirow{4}{*}{$\begin{array}{c}6.53 * \\
(0.089)\end{array}$} \\
\hline & Vocat.sch ${ }^{\mathrm{b}}$ & $100(19.7)$ & 36.00 & 32.00 & & 116.00 & 42.75 & & 40.00 & 10.00 & \\
\hline & Bachelor $^{\mathrm{c}}$ & $305(60.2)$ & 44.00 & 24.00 & & 120.00 & 25.50 & & 40.00 & 15.00 & \\
\hline & Postgradu $^{\mathrm{d}}$ & $40(7.9)$ & 52.00 & 19.00 & & 123.50 & 24.75 & & 37.50 & 19.75 & \\
\hline \multirow{5}{*}{$\begin{array}{l}\text { Working year } \\
13.16 \pm 8.87 \\
(1-39)\end{array}$} & $1-5^{a}$ & $137(27.0)$ & 40.00 & 28.00 & \multirow{5}{*}{$\begin{array}{c}11.48 * \\
(\mathbf{0 . 0 2 2}) \\
\mathrm{a}<\mathrm{d}\end{array}$} & 120.00 & 30.00 & \multirow{5}{*}{$\begin{array}{l}8.95^{*} \\
(0.062)\end{array}$} & 31.00 & 19.00 & \multirow{5}{*}{$\begin{array}{c}31.65^{*} \\
(\mathbf{0 . 0 0 1 )} \\
a>b, a>c, a>d, a>e\end{array}$} \\
\hline & $6-10^{b}$ & $92(18.7)$ & 44.00 & 24.00 & & 120.00 & 36.50 & & 40.00 & 13.00 & \\
\hline & $11-15^{\mathrm{c}}$ & $68(13.4)$ & 40.00 & 32.00 & & 120.00 & 29.75 & & 40.00 & 7.75 & \\
\hline & $16-20^{d}$ & $90(17.8)$ & 48.00 & 26.00 & & 120.00 & 23.00 & & 40.00 & 13.00 & \\
\hline & $20+^{e}$ & $117(23.1)$ & 44.00 & 28.00 & & 120.00 & 23.00 & & 40.00 & 14.00 & \\
\hline \multirow{2}{*}{$\begin{array}{l}\text { Department of } \\
\text { work }\end{array}$} & Surgical & $305(60.2)$ & 44.00 & 28.00 & \multirow{2}{*}{$\begin{array}{c}U=29599.00 * * \\
p=0.454\end{array}$} & 120.00 & 26.50 & \multirow{2}{*}{$\begin{array}{c}U=30004.50 * * \\
p=0.618\end{array}$} & 40.00 & 15.00 & \multirow{2}{*}{$\begin{array}{c}\mathrm{U}=29586.00 * * \\
p=0.414\end{array}$} \\
\hline & Medical & $202(39.8)$ & 44.00 & 28.00 & & 120.00 & 29.50 & & 40.00 & 15.25 & \\
\hline Working unit & Clinic $^{\mathrm{a}}$ & $268(52.9)$ & 44.00 & 24.00 & $8.65^{*}$ & 120.00 & 27.75 & & 38.00 & 16.75 & $13.89 *$ \\
\hline & $\mathrm{ICU}^{\mathrm{b}}$ & $132(26.0)$ & 42.00 & 24.00 & $(0.013)$ & 120.00 & 22.50 & $\begin{array}{l}3.59^{*} \\
(0.166)\end{array}$ & 38.00 & 16.00 & (0.001) \\
\hline & Other $^{\mathrm{c}}$ & $107(21.1)$ & 36.00 & 28.00 & $\mathrm{c}<\mathrm{a}$ & 120.00 & 35.00 & $(0.166)$ & 40.00 & 3.00 & $a>c, b>c$ \\
\hline Working & Staff nurse & $472(93.1)$ & 44.00 & 28.00 & $U=7921.00^{* *}$ & 120.00 & 26.75 & $U=7281.00 * *$ & 40.00 & 15.00 & $U=7347.00 * *$ \\
\hline position & Mane.nurs & $35(6.9)$ & 44.00 & 28.00 & $p=0.684$ & 120.00 & 31.00 & $p=0.239$ & 40.00 & 13.00 & $p=0.237$ \\
\hline
\end{tabular}

IQR: interquartile range, *Kruskal Wallis Test, **Mann Withney U Test:U, S1or S2:State 1 or 2, H: Hospital, ICU: Intensive care unit, LEK: Lymphedema Knowledge,

TBLEP : Teaching Behaviors towards LE Prevention, TALEP: Teaching Attitudes towards Lymphedema Prevention, 
Table 4. Nurses' TBLEP situations related of LE characteristics $(n=507)$.

\begin{tabular}{lccccc}
\hline & & \multicolumn{2}{c}{ TBLEP Situations } & $\begin{array}{c}\text { Statistical } \\
\text { significance test }\end{array}$ \\
\hline & & & was done & not done & \multicolumn{1}{c}{$X^{2}(p$ value $)$} \\
\hline Do you know what is LE? & & $\mathrm{n}(\%)$ & $\mathrm{n}(\%)$ & 4.85 \\
& Yes & $428(84.4)$ & $146(34.1)$ & $282(65.9)$ & $(0.028)^{*}$ \\
\hline Do you know how LE develops? & No & $79(15.6)$ & $17(21.5)$ & $62(78.5)$ & 13.10 \\
& Yes & $293(57.8)$ & $113(38.6)$ & $180(61.4)$ & $(0.001)^{*}$ \\
\hline Have you been educated about LE during & No & $214(42.2)$ & $50(23.4)$ & $164(76.6)$ & 7.88 \\
your working life? & No & $148(29.2)$ & $61(41.2)$ & $87(58.8)$ & $(0.005)^{*}$ \\
\hline Do you think you have sufficient & Yes & $84(16.6)$ & $37(44.0)$ & $47(56.0)$ & 6.53 \\
knowledge about LE? & No & $423(83.4)$ & $126(29.8)$ & $297(70.2)$ & $(0.011)^{*}$ \\
\hline Are there LE patients in the unit you & Yes & $212(41.8)$ & $91(42.9)$ & $121(57.1)$ & 19.39 \\
work in? & No & $295(58.2)$ & $72(24.4)$ & $223(75.6)$ & $(0.001)^{*}$ \\
\hline Are patients with cancer surgery & Yes & $81(16.0)$ & $45(55.6)$ & $36(44.4)$ & 24.21 \\
informed about LE? & No & $426(84.0)$ & $118(27.7)$ & $308(72.3)$ & $(0.001)^{*}$ \\
\hline Are education material on LE given to & Yes & $8(1.6)$ & $5(62.5)$ & $3(37.5)$ & 3.43 \\
patients? & No & $499(98.4)$ & $158(31.7)$ & $341(68.3)$ & $(0.064)$ \\
X2:Pearson Chi-Square, * $<<0.05$, TBLEP: Teaching & Behaviors towards Lymphedema Prevention, & & $102(28.4)$ & $257(71.6)$ & \\
\end{tabular}

The regression model established to test the effect of TBLEP precursors (LEK, TALEP, presence of LE patients in the working unit, department of working, working year, gender) on behavior is statistically significant $(F=11.075 ; p<0.01)$. On the other hand, when the individual significance tests are considered, the level of knowledge significantly and positively affects the teaching behavior $(\beta=.147 ; \quad t=-3.333$; $p=0.001$ ), and the attitude does not have a positive but statistically significant effect on the emergence of the behavior $(\beta=.065$; $t=1.503 ; p=0.133)$, it was observed that the presence of LE patients in the unit studied significantly and negatively affected the emergence of the behavior $(\beta=-, 164 ; t=-3,829$; $p=0.000)$. The unit worked has a significant negative effect $(\beta=-, 112 ; t=-2,603 ; p=0.010)$ in the emergence of the behavior, and the working year has a significant negative effect on the emergence of the behavior (those with less working years reveal more behavior) ( $\beta=-$ ,154; $t=-3,514 ; p=0.000)$, it was also observed that gender was positively (behavior more in men) and significant $(\beta=, 101 ; t=2,315$; $p=0.021)$ in the emergence of TBLEP. When we look at the explanation power of these variables in the model, the explanation power of the model is $10.7 \%$ (Table 5).

Table 5: The factors and their effect levels that are considered to have an effect on nurses' TBLEP.

\begin{tabular}{cccccccc} 
& $\begin{array}{c}\text { Standardized } \\
\text { Coefficients } \\
\text { Beta }(\beta)\end{array}$ & $\mathrm{t}$ & Sig. & $\begin{array}{c}95,0 \% \text { Confidence Interval } \\
\text { for B } \\
\text { Bound }\end{array}$ & $\begin{array}{c}\text { Lower } \\
\text { Upper Bound }\end{array}$ & Statistics \\
\hline (Constant) & & & & & & Tolerance & VIF \\
\hline LEK scores & .147 & 3.333 & .001 & .027 & .104 & .906 & 1.104 \\
\hline TALEP scores & .065 & 1.503 & .133 & -.005 & .040 & .956 & 1.046 \\
\hline $\begin{array}{c}\text { Presence of LE patients in } \\
\text { the working unit }\end{array}$ & -.164 & -3.829 & .000 & -4.099 & -1.319 & .962 & 1.039 \\
\hline Department of working & -.112 & -2.603 & .010 & -2.007 & -.280 & .950 & 1.052 \\
\hline Working year & -.154 & -3.514 & .000 & -1.276 & -.361 & .916 & 1.092 \\
\hline Gender & .101 & 2.315 & .021 & .397 & 4.861 & .925 & 1.082 \\
\hline
\end{tabular}

VIF: Variance İnflation Factor， Adjusted R Square $=0.107$ ， Durbin-Watson=1.594

\section{Discussion}

\section{Are the nurses' levels of knowledge about LE sufficient?}

Although the potential impact of LE is broad, it is largely unrecognized and undiagnosed. ${ }^{22}$ In this study, nurses stated that, they know what LE is $(84.4 \%)$, but half of them have a lack of knowledge about how it develops, $70.8 \%$ of them do not receive training about LE during their working life, and four-fifths of them thought that they had insufficient knowledge on LE. If nurses know the definition, cause, physiology, assessment, 
treatment and prevention of LE, it provides early assessment of LE risk and rapid recognition of symptoms. ${ }^{13}$ In this study, nurses' number unknown was found to be high in all of the questions of risk factors affecting the development of LE. It was also observed that LE risk factors were not sufficiently known by the nurses. Other questions were more commonly known, excluding 'When to start Extremity Circumference Measurements', 'How often should the patient examine herself/himself' and LE signs and symptoms of tingling, rash and restricted movement. Any procedure that affects the lymphatic system can pose a lifelong risk of LE. Fu and Rosedale ${ }^{9}$ stated in his study that most of the doctors and nurses do not know how to educate patients undergoing breast surgery, and most of the patients do not receive basic information about the LE risk. Conway's ${ }^{23}$ literature review emphasizes that all health disciplines, including surgeons, oncologists, breast care nurses, physical therapists, and family physicians, lack of knowledge of the 'risks' and 'perceived triggers' of BCRL development. In the study of Tam et al. ${ }^{24}$, breast cancer survivors reported their dissatisfaction with the training of clinicians on BCRL risk. They looked at BCRL knowledge levels in a study with 887 surgeons, oncologists, and primary care clinicians. In particular, female clinicians had higher knowledge scores than males and those who worked longer in the profession. In this study; females $(p=0.008)$, employees with 16 20 years working experience $(p=0.022)$, working in the clinic ( $p=0.013)$, the knowing scores were observed significantly higher. Providing effective care depends on continuing education, knowledgeable, skilled and willing nurses. Tuna and Soylu ${ }^{11}$ stated that nurses explained the practices they should or should not do to their patients with axillary lymph node dissection after breast cancer, since they only identify LE with breast cancer, and that their knowledge of lower extremity lymphedema was insufficient, and that they received training on this subject only in breast surgery during their LE training period. Nurses are expected to have sufficient knowledge to protect patients at risk for LE after cancer surgery. First of all, the nurse should know which behaviors should be avoided in terms of protecting patients at risk. It is important for nurses to be knowledgeable about LE so that they can take appropriate precautions and teach the patient. In our study, the nurses' knowledge was calculated over 100 points and their knowledge level was found to be $43.18 \pm 18.38$ below the average. It was observed that they did not have enough LE knowledge. When the knowledge scores were categorized, the scores obtained by the nurses were as follows: 331 nurses $(65.3 \%)$ between $0-49,141$ nurses $(27.8 \%)$ 50-75, 35 nurses 76 and above $(6.9 \%)$. The reason for this is that even though they have been trained on LE during their education, we think that they do not have a command of the subject as they do not update information on this subject as an inservice training.

\section{What are the nurses' attitude levels towards patient education to prevent LE?}

Although it is accepted that clinical nurses are among their legal responsibilities in studies, it has been determined that most of them do not see patient education as their role and their performance in this regard is not sufficient. ${ }^{18,19,25,26}$ Karayurt et al. ${ }^{26}$ trained nurses with a training program on LE prevention, signs and symptoms, and care of patients with BCRL. Nurses explained the necessity and functionality of education "I knew before the training that I was lacking in knowledge, but I really understood it more after the training". The nurses described their situation as increased confidence, improved knowledge, and increased awareness of professional issues related to breast cancer. At the end of the study, nurses developed more global goals regarding the roles of nursing (creating educational materials for patients, using the media for community education, etc.). Tuna and Soylu ${ }^{11}$, in their study with 10 nurses working in the surgical service, revealed that nurses' knowledge of LE is upto-date, sufficient to apply their knowledge, and their motivation to gain LE preventive behaviors to patients is low, and they need to be motivated for planned, scheduled, continuous training took off. Suhonen and 
Leino-Kilpi ${ }^{25}$ differenced between the views of nurses and patients' perceptions about the importance of informational needs were identified in his literature review. For example, patients ranked situational information, explaining activities and events, as the most important information content, whereas nurses ranked psychosocial support as the most important. Alsharif et al. ${ }^{27}$ conducted a study to determine the level of awareness of BCRL among women with breast cancer. They stated that in total, 95 out of 135 of participants did not know about lymphedema, $88.1 \%$ of the participants did not receive any explanation about the possibility of lymphedema before surgery, and $89.6 \%$ of them after surgery from their medical team. Yildirim et al. ${ }^{19}$ found that $67.2 \%$ of the nurses did not believe in the necessity of patient education and $55.3 \%$ did not provide patient education. In our study, nurses' attitude levels towards the subject of instruction were high $111.65 \pm 30.40$ (min$\max =20-140$ ). If nurses have positive thoughts about teaching LE prevention, it creates an expectation that it will increase the rate of doing it.

\section{Do nurses teach patients towards LE prevention?}

Patients who do not know what LE is and how to detect them may not notice swelling and report symptoms. ${ }^{15}$ Education and training will be key components of efforts to provide appropriate care for LE patients. Informing patients about lymphedema can contribute to reduce their risk of developing the condition or prevent further progression among those already affected. Patients should be avoid high-risk behaviors, and they should told about the possible symptoms of LE and where to go if these symptoms occur. In this study, the ratio of nurses who do not do the behaviors of LE prevention was $75.3 \%$, and nurses' TBLEP scores were found to be $26.49 \pm 8.16 \quad(\min -\max =20-40)$. It was observed that the nurses did not teach enough. Studies have found that the degree of involvement of patient education in nurses' practices was minimal, and it was stated that most of the patients were not informed about the signs, symptoms or risk factors of lymphedema at their preoperative or postoperative visits. Borman et al. ${ }^{28}$ were conducted a study to evaluate postoperative information and education on lymphedema in 180 lymphedema patients associated with breast cancer surgery. The patients were asked if they had received any information about lymphedema awareness or whether they received training to reduce the risk of lymphedema after breast cancer surgery. Only $19.5 \%$ of the participants reported that they received information or training about lymphedema, and $80.5 \%$ did not. Choi et al. ${ }^{8}$ conducted a cross-sectional study with 116 breast cancer patients; $20.68 \%$ of the patients stated that they had no idea about LE, and $25.86 \%$ stated that they received an explanation about the possibility of LE before the operation. Only $17.25 \%$ knew that LE was not a completely curable disease, while $20.68 \%$ felt that LE did not require any treatment. Many patients reported worryingly that they were not given the information they needed. It is observed that most of the patients perceive that they are not ready enough for discharge. However, patients who received LE information had higher knowledge scores and lower LE symptoms than those who did not. ${ }^{8}$ Although written material is given to the patients before discharge, the information in it is not explained in a planned, scheduled, and definite period. Written materials are preferred by patients, but they need to be carefully prepared and developed for use by different patients with different information needs. The fact that they are both written and spoken information increases knowledge. ${ }^{25}$ Sherman and Koelmeyer ${ }^{29}$ reported that information delivered by clinical staff or booklets and brochures about lymphedema, played an important role in minimizing the risk of lymphedema. In this study, for the question of "Are patients with cancer surgery informed about LE?" $84.0 \%$ of the nurses and for the question of "Are education material on LE given to patients?" $98.4 \%$ of them gave the answer as no. It is thought that this may be due to the high workload of nurses or the fact that they do not see it as their own duty. 


\section{What are the factors affecting Nurses' Teaching Behaviors towards LE Prevention?}

Tolu and Basim $^{30}$ emphasizes the lack of awareness of lymphedema in a study with 250 survivors of breast cancer. In particular, cancer survivors are at risk for the long-term effects of treatment, such as lymphedema, and have expressed a need for adequate follow-up care and information to help them cope with their risks. Nurses state that they cannot fulfill planned education, which is one of their main roles, due to the excessive number of patients, lack of materials, lack of time, incomplete information and the lack of patient education expectation. Factors such as nurses' inefficient use of time, large number of patients, insufficient job satisfaction and motivation, indifference of managers, and inappropriate clinical environment affect patient education. ${ }^{19}$ To effectively educate patients about LE, clinical knowledge and the proportion of clinicians should be sufficient. ${ }^{18}$ See et al. $^{32}$ conducted a descriptive, exploratory qualitative research included eight focus groups of 35 nurses. They yielded three themes: 'Role ambiguity' between the levels of nurses concerning their roles in patient education; 'Not a priority nursing care' for patient education due to competing work demands and the missing workplace culture to teach; and 'Informal teaching' carried out conversationally during nursing care activities. And highlighted at the end of their work that nurse managers and educators are instrumental in establishing role clarity between ward nurses and special care nurses for patient education, accepting patient education for reflecting quality of care, and fostering positive workplace cultures for teaching and teaching. Yildirim et al. ${ }^{19}$ in their study in which they investigated the factors affecting nurses' patient education, they reported that there was no patient education due to reasons such as nurses had excessive workload $(86.8 \%)$, could not use time effectively $(75.1 \%)$, thought that patients did not want to receive education (37\%), had a shortage of professional nurses in patient education (47.9\%), patient education activities are not given priority in clinics (
23\%). Tsuchiya et al. ${ }^{31}$ in with their study, public health nurses' knowledge, training needs about LE risk-reduction strategies, and intention and perceptions of the barriers regarding organizing community-based LE education programs were examined. Over $70 \%$ of this sample had previous clinical experience in the care provision for patients with cancer and more than half of these respondents had experience in the care provision for patients with cancer in their current workplace. Around $68 \%$ of the participants reported that carrying out such programs would be difficult for them. The reasons for these perceptions of difficulty were that the nurses were unsure of the needs of patients with cancer in their education program $(72.2 \%)$, they perceived the human resources in their workplace to be insufficient $(59.3 \%)$, they perceived their medical knowledge to be insufficient (52.2\%). Davies et al. $^{33}$ conducted a study with general practitioners, nurses and allied health professionals working in fields such as primary care, community care, outpatient clinics, oncology and palliative care. In their study have stated that poor knowledge of lymphoedema among clinicians can delay its management, increasing the burden on affected individuals, carers, and services. They have emphasized Clinicians have unmet education needs that are profession and healthcare setting specific and Gaps in knowledge contribute to a feeling of professional impotence among both generalists and specialists, as they are unable to provide consistency of care across different care settings. They have declarated that lymphoedema knowledge has the potential to improve, care, and managing patients with lymphoedema to. İn their study confirmed that clinicians have unmet educational needs relating to lymphoedema, and found that these are specific to professional groups and healthcare settings. Lack of knowledge and constraints have imposed that both generalists and specialists feeling professionally impotent and unable to provide consistency of care across care settings. In this study, with the results of multiple regression analysis, factors affecting TBLEP was found as "LEK scores", "TALEP scores", "presence of LE patients in 
the working unit", "department of working", "working year" and "gender". It was observed that as the level of knowledge increased, the teaching behavior also increased, but the attitude was not effective in behavior. Nurses working in surgical units show more LE prevention teaching behavior. In connection with this, nurses may have reduced the risk of LE patients as they applied more teaching behaviors to cancer surgery patients. Naturally, nurses who are younger and have less working years are more active in patient teaching. Therefore, for the correct management of lymphedema, training protocols should be developed according to influencing factors.

\section{Limitations}

The study has some limitations. The most objective way of measuring knowledge and attitude of a nurse may be observing and evaluating him/her during real patient followup, care and education. The nurses were asked to fill out the questionnaires using the selfreport method during rest breaks. As the research data were collected by face-to-face interview method only represent this nurse sample and the reliability of the data is limited to the responses given by the nurses, they cannot be generalized. Another limitation of our study is that some departments did not have any LE patients and also all nurses, not just caregivers of patients undergoing cancer surgery, were included in the study. It was desired to evaluate the LE knowledge, attitude and behavior of the nurses included in the sample, but since the majority of the nurses did not encounter LE patients, the effect of this emerged in the regression.

\section{Conclusion}

This was the first study among nurses to investigate LE knowledge level, attitude levels of nurses towards teaching prevention from LE, and their teaching behavior. The study showed that the LE knowledge of nurses and TBLEP scores was low. Nurses' attitude levels towards teaching prevention of LE is positive in moderate level. The positive or negative attitudes of nurses towards LE prevention teaching, in relation to their level of knowledge, greatly affect patient education. Therefore, it will be important for patient education to increase the knowledge level of nurses in patient education for LE prevention. It should be ensured that LE prevention education is continuous and standardized and this culture is established in the hospitals they work in. Nurses play a key role in spreading LE information and persuading patients to follow recommendations. The study results show that there is an intense need to develop an education program for nurses regarding the possibility of LE occurrence, especially for patients who have undergone cancer surgery. Consequently, with the increasing number of cancer survivors, nurses need to increase their training on LE to prevent the risk of postoperative lymphedema after cancer surgery. As a solution, not all nurses may be able to provide lymphedema prevention training, but an assigned in-hospital lymphedema training nurse should train them about lymphedema and prevention before and after surgery for all cancer patients.

\section{Ethics Committee Approval}

For conducting the study, the Aydin Adnan Menderes University's Nursing Faculty NonInterventional Clinical Research Ethics Committee permission (50107718-050.04.04), written permission from the specified hospitals are taken.

\section{Informed Consent}

The consent of the nurses participating in the study were given after the purpose of the study was explained. It was also assumed that all survey questions were answered truthfully by the nurses, because confidentiality was maintained throughout the study. All nurses participated on a voluntary basis and were allowed at any time to withdraw from the research. The research was conducted in compliance with the Helsinki declaration.

\section{Author Contributions}

Concept, Design, Supervision, Fundings, Materials, Data Collection and/or Processing, Analysis and/or Interpretation, Literature Search, Writing Manuscript and Critical Review: SÖ 


\section{Acknowledgments}

We thanks to participated nurses in this study

\section{Conflict of Interest}

No conflict of interest was declared by the author.

\section{Financial Disclosure}

The author declared that this study has received no financial support.

\section{Peer-review}

\section{Externally peer-reviewed}

\section{References}

1. Fu MR, Kang Y. Psychosocial impact of living with cancerrelated lymphedema. Semin Oncol Nurs. 2013;29(1):50-60. doi:10.1016/j.soncn.2012.11.007

2. Oz BS, Sargin M, Iyem H, et al. The incidence and factors influencing lymphedema in lower extremities. Turkish J Thorac Cardiovasc Surg. 2006;14(4):304-307.

3. Cormier JN, Askew RL, Mungovan KS, Xing Y, Ross MI, Armer JM. Lymphedema beyond breast cancer. Cancer. 2010;116(22):5138-5149. doi:10.1002/cncr.25458

4. Mendivil AA, Rettenmaier MA, Abaid LN, et al. Lowerextremity lymphedema following management for endometrial and cervical cancer. Surg Oncol. 2016;25(3):200-204. doi:10.1016/j.suronc.2016.05.015

5. Wanchai A, Armer JM, Stewart BR, Lasinski BB. Breast cancer-related lymphedema: A literature review for clinical practice. Int J Nurs Sci. 2016;3(2):202-207. doi:10.1016/j.ijnss.2016.04.006

6. Tsuchiya M, Masujima M, Kato T, et al. Knowledge, fatigue, and cognitive factors as predictors of lymphoedema riskreduction behaviours in women with cancer. Support Care Cancer. 2019;27(2):547-555. doi:10.1007/s00520-018-4349-0

7. Arikan Donmez A, Kapucu S. Management of breast cancerrelated lymphedema. Turkish J Oncol. 2016;31(4):138-148. doi:10.5505/tjo.2016.1496

8. Choi JK, Kim HD, Sim YJ, et al. A survey of the status of awareness of lymphedema in breast cancer patients in BusanGyeongnam, Korea. Ann Rehabil Med. 2015;39(4):609-615. doi:10.5535/arm.2015.39.4.609

9. Fu MR, Rosedale M. Breast cancer survivors' experiences of lymphedema-related symptoms. J Pain Symptom Manag. 2009;38(6):849-859. doi:10.1016/j.jpainsymman.2009. 04.030

10. Lindqvist $\mathrm{E}$, Wedin $\mathrm{M}$, Fredrikson M, Kjølhede $\mathrm{P}$. Lymphedema after treatment for endometrial cancer - A review of prevalence and risk factors. Eur J Obstet Gynecol Reprod Biol.2017;211:112-121. doi:10.1016/j.ejogrb.2017. 02.021

11. Tuna A, Soylu A. Nurse experience in lymphedema and care: a study on lymphedema. KSU Med J. 2020;15(1):64-68. doi:10.17517/ksutfd.560240

12. Paskett ED, Stark N. Lymphedema: Knowledge, treatment, and impact among breast cancer survivors. Breast J. 2000;6(6):373378. doi:10.1046/j.1524-4741.2000.99072.x

13. Wilson D. The effect of education on healthcare personnel's knowledge of lymphedema detection and prevention [Master thesis]. Hunt School of Nursing, Gardner-Webb University, Published online 2012. http://digitalcommons.gardnerwebb.edu/cgi/viewcontent.cgi?article $=1147 \&$ context=nursing _ etd

14. Yu SY, Kim JH. Lower limb lymphedema and quality of life in gynecologic cancer patients. Asian Oncol Nurs. 2017;17(1):20. doi:10.5388/aon.2017.17.1.20

15. Abu Sharour L. Oncology nurses' knowledge about lymphedema assessment, prevention, and management among women with breast cancer. Breast Dis. 2019;38(3-4):103-108.

\section{doi:10.3233/BD-190381}

16. Avsar G, Kasikci M. Evaluation of patient education provided by clinical nurses in Turkey. Int J Nurs Pract. 2011;17(1):6771. doi:10.1111/j.1440-172X.2010.01908.X

17. Civelek GM, Aypak C, Turedi O. Knowledge of primary care physicians about breast-cancer-related lymphedema: Turkish perspective. J Cancer Educ. 2016;31(4):687-692. doi:10.100 7/s13187-015-0880-6

18. Simmons HM. Preoperative lymphedema education for breast

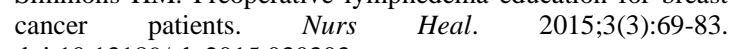
doi:10.13189/nh.2015.030303

19. Yildirim N, Ciftci B, Kasikci M. Determining the factors affecting and the practice of patient education among nurses. $J$ Ataturk Commun. 2017;14:217-230.

20. Ayre C, Scally AJ. Critical values for Lawshe's content validity ratio: Revisiting the original methods of calculation. Meas Eval Couns Dev. 2014;47(1):79-86. doi:10.1177/ 0748175613513808

21. Lawshe CH. A Quantitative approach to content validity. Pers Psychol. 1975;28(4):563-575. doi:10.1111/j.1744-6570. 1975.tb01393.x

22. Armer JM, Radina ME, Porock D, Culbertson SD. Predicting breast cancer-related lymphedema using self-reported symptoms. Nurs Res. 2003;52(6):370-379. doi:10.1097/ 00006199-200311000-00004

23. Conway MM. Professional education on breastcancer-related lymphoedema and its relation to patient wellbeing. Wounds. 2016;12(3):22-29.

24. Tam EK, Shen L, Munneke JR, et al. Clinician awareness and knowledge of breast cancer-related lymphedema in a large, integrated health care delivery setting. Breast Cancer Res Treat. 2012;131(3):1029-1038. doi:10.1007/s10549-011-182 9$\mathrm{z}$

25. Suhonen R, Leino-Kilpi H. Adult surgical patients and the information provided to them by nurses: A literature review. Patient Educ Couns. 2006;61(1):5-15. doi:10.1016/ j.pec.200 5.02.012

26. Karayurt O, Gursoy AA, Tasc1 S, Gundogdu F. Evaluation of the breast cancer train the trainer program for nurses in Turkey. J Cancer Educ. 2010;25(3):324-328. doi:10.1007/ s13187-0100043-8

27. Alsharif F, Almutairi W, Shibily F, et al. The level of lymphedema awareness among women with breast cancer in the Kingdom of Saudi Arabia. Int J Environ Res Public Health. 2021;18(2):627. doi:10.3390/ijerph18020627

28. Borman P, Yaman A, Yasrebi S, Özdemir O. The importance of awareness and education in patients with breast cancer-related lymphedema. J Cancer Educ. 2017;32(3):629-633. doi:10.1007/s13187-016-1026-1

29. Sherman KA, Kilby CJ, Elder E, Ridner SH. Factors associated with professional healthcare advice seeking in women at risk for developing breast cancer-related lymphedema. Patient Educ Couns. 2018;101(3):445-451. doi:10.1016/j.pec.2017.10.010

30. Tolu S, Basim P. Awareness of lymphedema risk management behaviors and associated factors among breast cancer survivors: Results from a cross-sectional survey. Ann Med Res. 2020;27(1):97. doi:10.5455/annalsmedres. 2019.11 .779

31. Tsuchiya M, Morı M, Takahashi M, Masujıma M. Communitybased lymphedema risk reduction programs for cancersurvivors: An Internet survey of public health nurses. Japan Journal of Nursing Science 2018;15:340-350. doi:10.1111/jjns.12204

32. See MTA, Chee S, Rajaram R, Kowitlawakul Y, Liaw SY. Missed nursing care in patient education: A qualitative study of different levels of nurses' perspectives. J Nurs Manag. 2020;00:1-8. doi:10.1111/jonm.12983

33. Davies R, Fitzpatrick B, O’Neill A, Sneddon M. Lymphoedema education needs of clinicians: A National study. Journal of Lymphoedema. 2012; 7(2): 14-24 